\title{
Field evaluation of self propelled reaper cum binder through front line demonstration in wheat crop in Indore district of Madhya Pradesh
}

\section{Jitendra Singh}

Author for Correspondence :

Jitendra Singh Krishi Vigyan Kendra, Kasturbagram, Indore (M.P.) India
- ABSTRACT : Field performance of self propelled reaper cum binder was assessed in wheat crop and compared with manual method of harvesting by sickle at farmer's field under the front line demonstration during Rabi 2015-16 and 2016-17 in the village Ramukhedi, Setkhedi, Khudel and Naharkheda at 20 farmers field. The effective field capacity of the self propelled reaper cum binder was found $0.253 \mathrm{ha} \mathrm{h}^{-1}$ with a field efficiency of 59.18 per cent at an average operating speed of 3.5 kmph compared to 0.025 ha ha $^{-1}$ for manual harvesting. The fuel consumption was found 4.971 $\mathrm{ha}^{-1}$. Labour requirements for mechanical and manual harvesting were 19.97 and 192 man-h ha ${ }^{-1}$, respectively. The harvesting losses for mechanical and manual harvesting were 69.37 and $68.04 \mathrm{~kg}$ $\mathrm{ha}^{-1}$, respectively. The cost of harvesting operation was Rs.9882/ha for manual harvesting and Rs. 2962/ha for mechanical harvesting. The harvesting cost of self propelled reaper cum binder was reduced by 70.02 per cent compared to manual harvesting method with sickle.

- KEY WORDS : Wheat, Self propelled reaper cum binder, Harvesting, Manual harvesting

- HOW TO CITE THIS PAPER : Singh, Jitendra (2018). Field evaluation of self propelled reaper cum binder through front line demonstration in wheat crop in Indore district of Madhya Pradesh. Internat. J. Agric. Engg., 11(2) : 359-363, DOI: 10.15740/HAS/IJAE/11.2/359-363. Copyright@ 2018: Hind AgriHorticultural Society. 